ACTA AGROBOTANICA

Vol. 61 (2): 25-34

2008

\title{
MICROMORPHOLOGY OF GLANDULAR STRUCTURES IN ECHIUM VULGARE L. FLOWERS
}

\author{
Elżbieta Weryszko-Chmielewska, Mirosława Chwil
}

\author{
Department of Botany, University of Life Sciences, Akademicka 15, 20-950 Lublin, Poland \\ e-mail: elzbieta.weryszko@.up.lublin.pl
}

Received: 8.10.2008

$$
\text { S u m m a r y }
$$

The micromorphology of selected elements of Echium vulgare L. flowers was investigated, with special attention to the structure of the nectaries and the stigma of the pistil as well as types of trichomes occurring on the surface of the calyx.

The nectary had the shape of an uneven disc located around the lower region of the four-parted ovary of the pistil. The glandular cells formed a tier with a height of $330 \mu \mathrm{m}$ and a radial width of $144 \mu \mathrm{m}$. Nectar was secreted onto the nectary surface through anomocytic stomata located at the level of other epidermal cells. Most of the stomata were open, with a different dimension of the pore. Their largest number was observed at the base of the nectary, and 462 stomata were noted on the whole surface of the nectary. The cuticle on the surface of the guard cells formed fine, circular striae. The subsidiary cells formed striated cuticular ornamentation, with the striae arranged radially in the direction of the stoma, whereas on the surface of other epidermal cells the striae formed an arrangement with different directions.

The epidermis on the surface of the stigma formed regularly arranged papillae with a fan-shaped, expanded upper part which had corrugated outer walls, whereas the base of the cell formed a widened small column.

The epidermis of the abaxial part of the calyx was covered by numerous non-glandular trichomes of different length which were made up of one or several cells. The glandular trichomes in the epidermis of the calyx grew with smaller density compared to the protective trichomes, and they were composed of a 1-2-celled stalk and a glandular head.

Key words: floral nectaries, stigma, calyx, trichomes, Echium vulgare, Boraginaceae

\section{INTRODUCTION}

Echium vulgare L. (Boraginaceae) is a widespread species in the flora of Poland. It grows on lowlands and in lower piedmont areas. It is encountered in ruderal phytocoenoses. This species prefers sandy, dry and warm soils. It frequently occurs on dry hills, in rock debris and stone embankments ( $\mathrm{S} \mathrm{z}$ a fe r, 1986; R u tk ow s k i, 2006).

Echium vulgare plants form a ground leaf rosette. Above-ground shoots may reach a height of $1 \mathrm{~m}$. They are densely haired, with hairs protruding. This species is distinguished by a long period of flowering which lasts from June to October. Its inflorescence is a cyme in which numerous tubular flowers are clustered. The blue, five-lobed, oblique corolla is twice longer than the calyx. The stamens (5) with red filaments project beyond the corolla ( $\breve{S}$ o $\mathrm{m}$ š a c, 1984).

Echium vulgare is included in nectar and pollen producing, medicinal and ornamental plants (Jabłoński, 1986; K ołtowski, 2006). This species is a poisonous plant. The nectar of this plant also has poisonous properties due to the content of pyrrolizidine alkaloids which may remain in honeys (B eales et al. 2004; B op pre at al. 2005).

The aim of the present study was to determine the micromorphology of floral glandular structures of Echium vulgare, including the nectary, the stigma of the pistil and trichomes occurring on the surface of the calyx. These structures play a great role in the pollination ecology of this species.

\section{MATERIALS AND METHODS}

Echium vulgare L. plants from which inflorescences were sampled came from the Botanical Garden of the Maria Curie-Skłodowska University in Lublin, Poland. Wild individuals growing in different parts of the city were also used.

The micromorphology of flowers was investigated using light and scanning electron microscopy (SEM). The size of the nectaries and the structure of the epidermis responsible for nectar secretion, the structure of cells from the surface of the stigma as well as the abaxial epidermis of the sepals were all analysed. 
For light microscopy analysis, semi-permanent slides, earlier treated with Lugol's iodine solution, were prepared in glycerol-gelatine. Pollen grains were stained with basic fuchsin.

The plant samples used for scanning electron microscopy analysis were fixed in glutaraldehyde, then dehydrated in acetone series and in acetone, and after drying at $\mathrm{CO}_{2}$ critical point, they were coated with gold using a Sputter Coater. The elements of the flower were observed using a microscope TESLA BS-300.

\section{RESULTS}

The Echium vulgare plants developed red buds and flowers with a purple corolla at the beginning of flowering (Fig. $1 \mathrm{~A}$ ). After the petals opened, the corolla changed its colour to blue (Fig. 1 B).

\section{Nectary}

The nectary gland in the Echium vulgare flowers formed an uneven ring or collar at the basal part of the four-parted ovary (Figs 2 A, B). The yellow-green nectary differed distinctly from the green ovary (Figs $1 \mathrm{C}-\mathrm{F}$ ). In particular flowers, the nectaries were different-sized (Figs 1 C, E, F). Some flowers developed a three-parted ovary (Fig. 1 F). The glandular cells of the nectary formed a tier with an average height of 330 $\mu \mathrm{m}$ and a radial width equal to $144 \mu \mathrm{m}$. The nectary accounted for about a half of the ovary height which reached $648 \mu \mathrm{m}$, on the average, whereas the ovary diameter was $960 \mu \mathrm{m}$ (Tab. 1).

Table 1

Characteristics of the nectary of Echium vulgare.

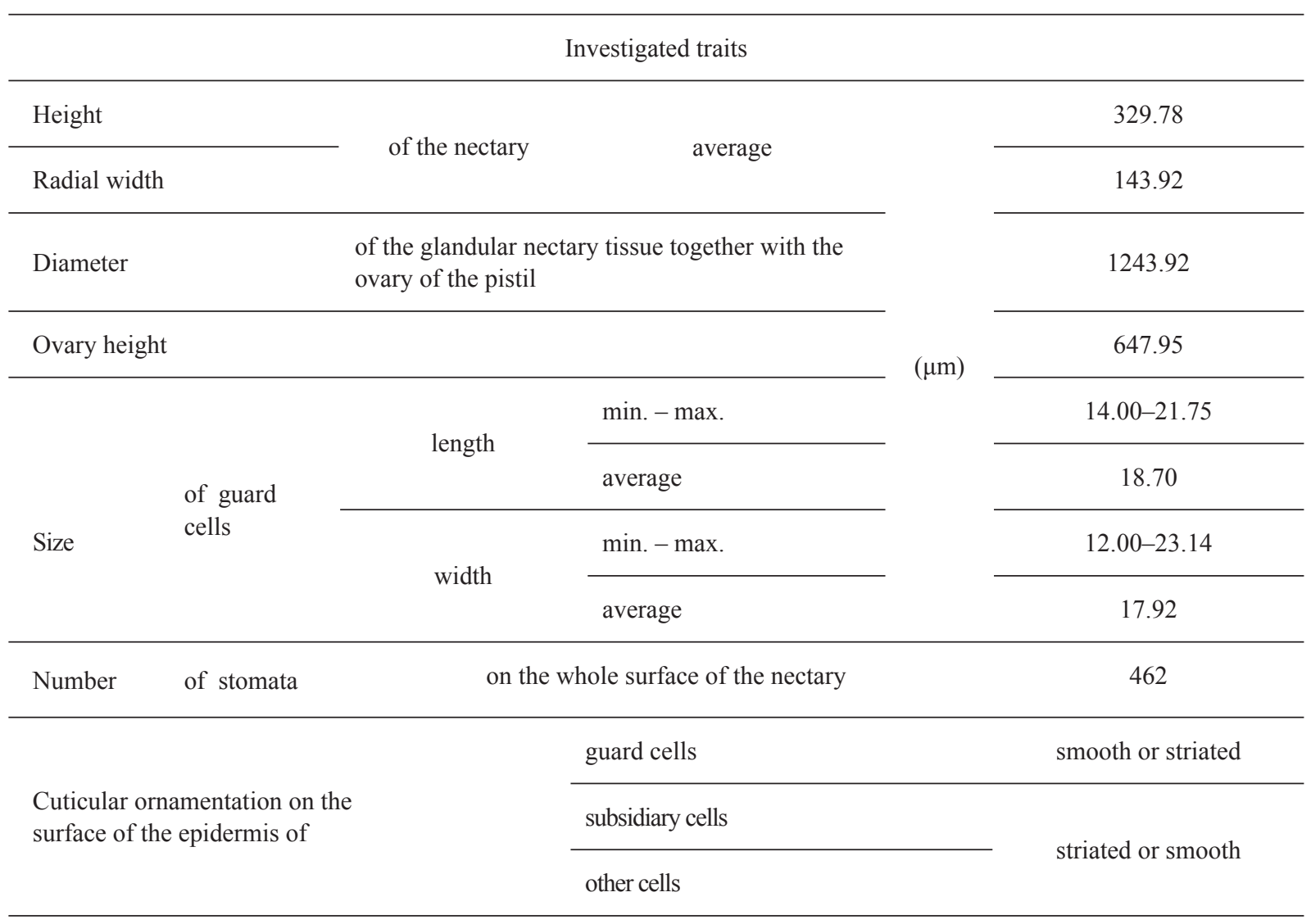

Nectar was secreted onto the nectary surface through anomocytic stomata distributed over the whole surface of the nectary epidermis (Fig. 2 C). The stomata occurred at the level of other epidermal cells (Fig. 2 D). Their largest number was observed in the lower part of the nectary. Most of the stomata were open, with a different dimension of the pore (Figs 2 E-I). The stomata were different-sized; their length and width were within the range of 14-22 $\mu \mathrm{m}$ and 12$23 \mu \mathrm{m}$, respectively, with the mean value equal to 19 $\mu \mathrm{m}$ and $18 \mu \mathrm{m}$, respectively. 
The cuticle on the surface of the guard cells was smooth or formed fine, circular striae around the aperture by which there were small, outer cuticular ledges. The cuticle covering subsidiary cells was distinguished by distinct striate ornamentation (Figs $2 \mathrm{G}, \mathrm{H}$ ). The striae were arranged radially in relation to the stoma, whereas on the surface of other epidermal cells they were arranged in different directions.

The number of stomata on the whole surface of the epidermis covering the nectary was within the range of $201-629$, with the mean value equal to 462 .

\section{Stigma}

The style of the pistil was covered with densely growing, long, non-glandular trichomes (Figs $1 \mathrm{C}, 2$ A). The branches of the style terminated in two capitate stigmas (Figs $3 \mathrm{~A}-\mathrm{C} ; 4 \mathrm{~A}, \mathrm{~B}$ ). The surface of the stigma was covered by unicellular papillae which have a characteristic structure. Their apical part forms a structure which resembles an umbrella with corrugated edges. In buds and very young flowers, the folds of the adjacent papillae tightly adhere to each other forming the upper, compact layer of the stigma (Figs 3 $\mathrm{C}, \mathrm{E}, \mathrm{F})$. The outer wall of each cell is slightly convex. On the wall surface, there is granular ornamentation formed by the cuticle (Figs 3 E, F). In older flowers, the arrangement of the papillae clearly becomes loose, probably as a result of their shrinking, thereby forming free spaces between them (Figs $3 \mathrm{~B}, \mathrm{D})$.

In longitudinal section of the stigma, the lower parts of the papillae are visible, resembling widened stalks or small columns bearing the apical part, fanshaped and with corrugated edges (Figs 4 B, C).

In the papillae viewed in cross section and from above, thick, light and undulate cell walls are noticeable. The protoplasts of these cells show intensive colouration. At some places between the separated papillae, embedded pollen grains are visible (Fig. 4 E). Tricolporate pollen grains of E. vulgare with a polar axis of $18 \mu \mathrm{m}$ are shown in (Figs $4 \mathrm{~F}, \mathrm{G})$.

\section{Trichomes in the calyx epidermis}

The abaxial epidermis covering the elements of the calyx develops densely growing, unicellular protective (non - glandular) hairs of different length and sparsely distributed several-celled glandular trichomes (Fig. 5 A). The epidermal cells are polygonal, of equal dimension. The number of protective hairs per $1 \mathrm{~mm}^{2}$ of the abaxial epidermis of the calyx was within the range of 296-399. These structures reached a length of from 256 to $1361 \mu \mathrm{m}$. Small wall protuberances occurred on their surface (Figs 5 B-D). Non-glandular trichomes were single- or several-celled.

Table 2

Characteristics of the epidermis of the calyx of Echium vulgare.

\begin{tabular}{|c|c|c|c|c|}
\hline \multicolumn{5}{|c|}{ Investigated trait } \\
\hline \multirow{2}{*}{ Number of } & protective trichomes & per $1 \mathrm{~mm}^{2}$ of & \multirow{2}{*}{ of sepals } & 328.25 \\
\hline & glandular trichomes & epidermis & & 118.98 \\
\hline \multirow{2}{*}{ Length of } & protective trichomes & in epidermis & \multirow{3}{*}{ of calyx } & $256.37-1360,71$ \\
\hline & stalk of & & & 17.52 \\
\hline Diameter of & head of & glandular trichomes & & 24.48 \\
\hline
\end{tabular}

The glandular hairs in the epidermis of the calyx grew with much smaller density compared to the protective trichomes. They were composed of a single- or two-celled stalk with an average length of 18 $\mu \mathrm{m}$ and a unicellular head with a diameter of $25 \mu \mathrm{m}$ (Tab. 2; Figs 5 A-D). The head of the hair was covered by a layer of cuticle, usually protruding at the place of secretion accumulation (Figs 5 B, D). 

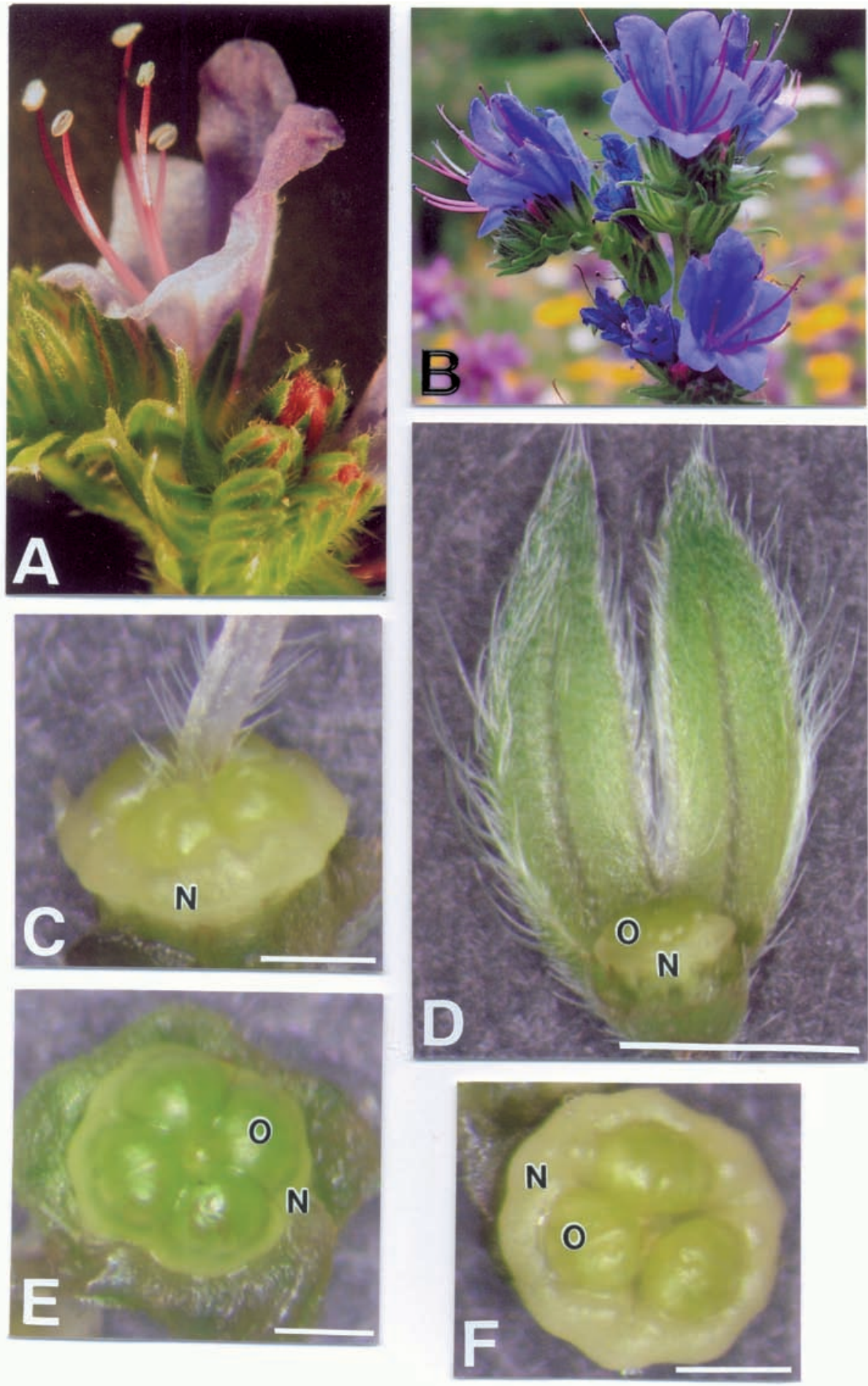

Fig. 1. Flowers and floral nectaries of Echium vulgare.

A - Flower on the first day of anthesis.

$\mathrm{B}$ - Flowers at full anthesis in the middle part of a helicoid cyme inflorescence.

$\mathrm{C}-$ Ovary of the pistil with the nectary $(\mathrm{N})$ and a portion of the style. Bar $=500 \mu \mathrm{m}$.

$\mathrm{D}$ - Portion of the longitudinally cut calyx with the ovary $(\mathrm{O})$ and nectary $(\mathrm{N})$ at the base. Bar $=200 \mu \mathrm{m}$.

E - Four-parted ovary $(\mathrm{O})$ with the nectary $(\mathrm{N})$ at the base. Bar $=500 \mu \mathrm{m}$.

F - Three-parted ovary $(\mathrm{O})$ with the nectary $(\mathrm{N})$. Bar $=500 \mu \mathrm{m}$. 

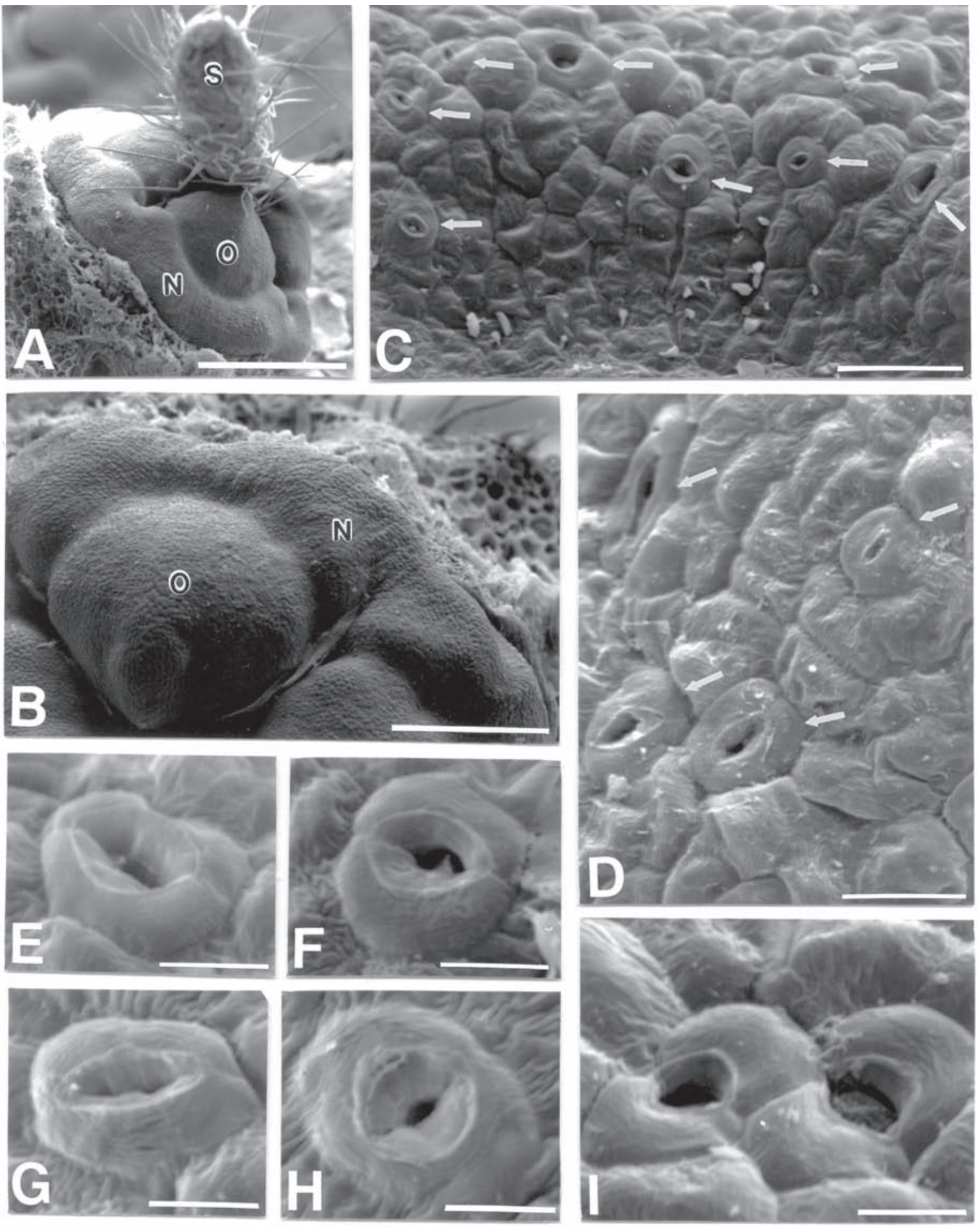

Fig. 2. Ovary with the nectary and surface portions of the nectaries.

A - Ovary $(\mathrm{O})$, portion of the haired style $(\mathrm{S})$ and the nectary $(\mathrm{N})$. Bar $=600 \mu \mathrm{m}$.

$\mathrm{B}$ - Portion of the ovary $(\mathrm{O})$ with the nectary gland at the base $(\mathrm{N})$. Bar $=300 \mu \mathrm{m}$.

C, D - Portions of the epidermis with stomata of different size (arrows) from the upper part of the nectary. C $-\mathrm{Bar}=30 \mu \mathrm{m}$, $\mathrm{D}-\mathrm{Bar}=20 \mu \mathrm{m}$.

E - I - Stomata from the nectary surface. Bar $=10 \mu \mathrm{m}$. 

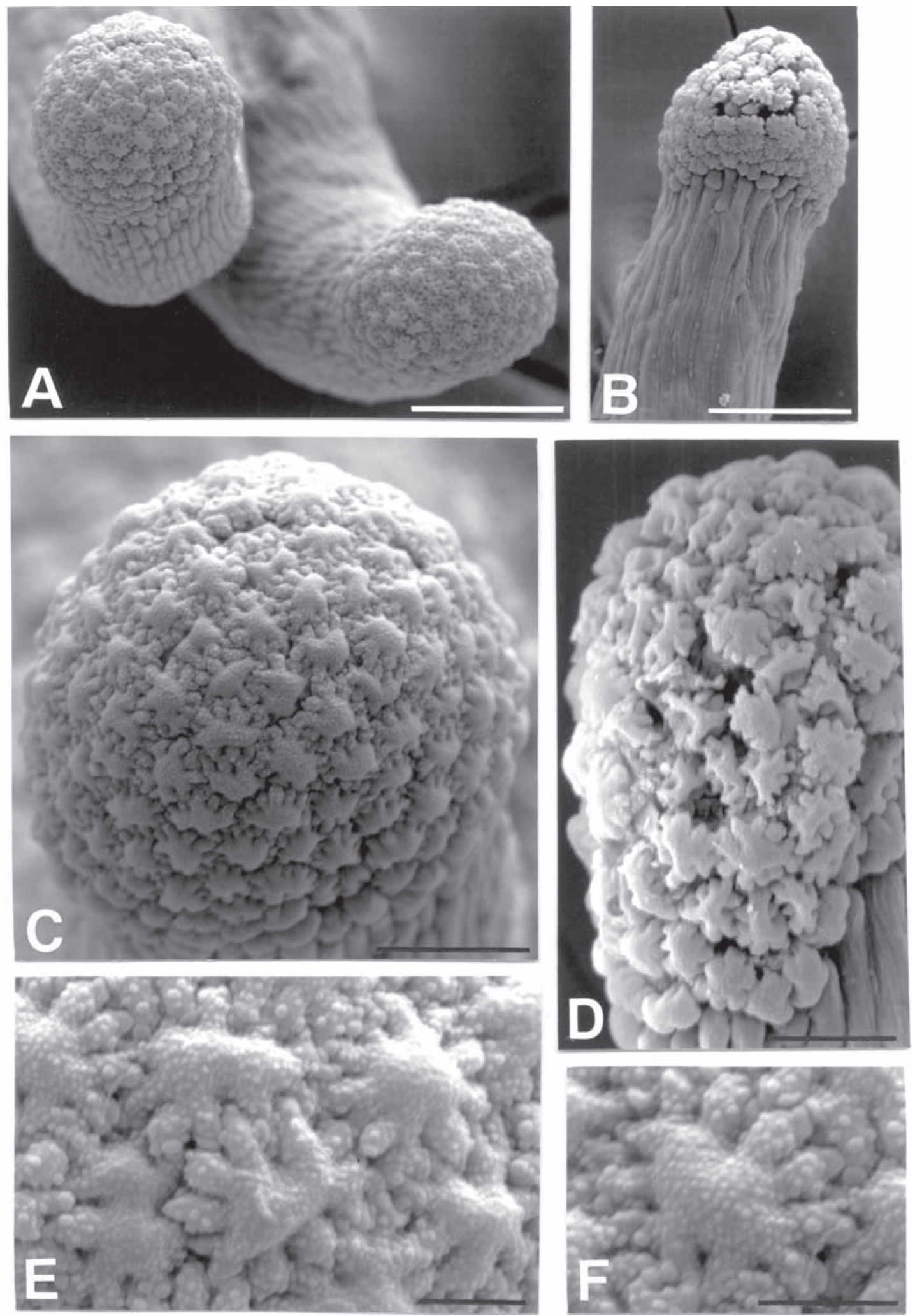

Fig. 3. Stigmas of the pistil of Echium vulgare (SEM).

A - Two circular stigmas at the apex of the style of the pistil from a flower bud. Bar $=90 \mu \mathrm{m}$.

$\mathrm{B}-$ Stigma of the pistil on the first day of flower anthesis. Bar $=100 \mu \mathrm{m}$.

C - Stigma of the pistil from a flower bud. Visible are tightly arranged papillae. Bar $=40 \mu \mathrm{m}$.

D - Portion of the stigma from flowers on the second day of anthesis. Visible are loose papillae. Bar $=30 \mu \mathrm{m}$.

E, F - Portions of the surface of the stigma from a flower bud with a compact arrangement of papillae. E, F - Bar $=10 \mu \mathrm{m}$. 

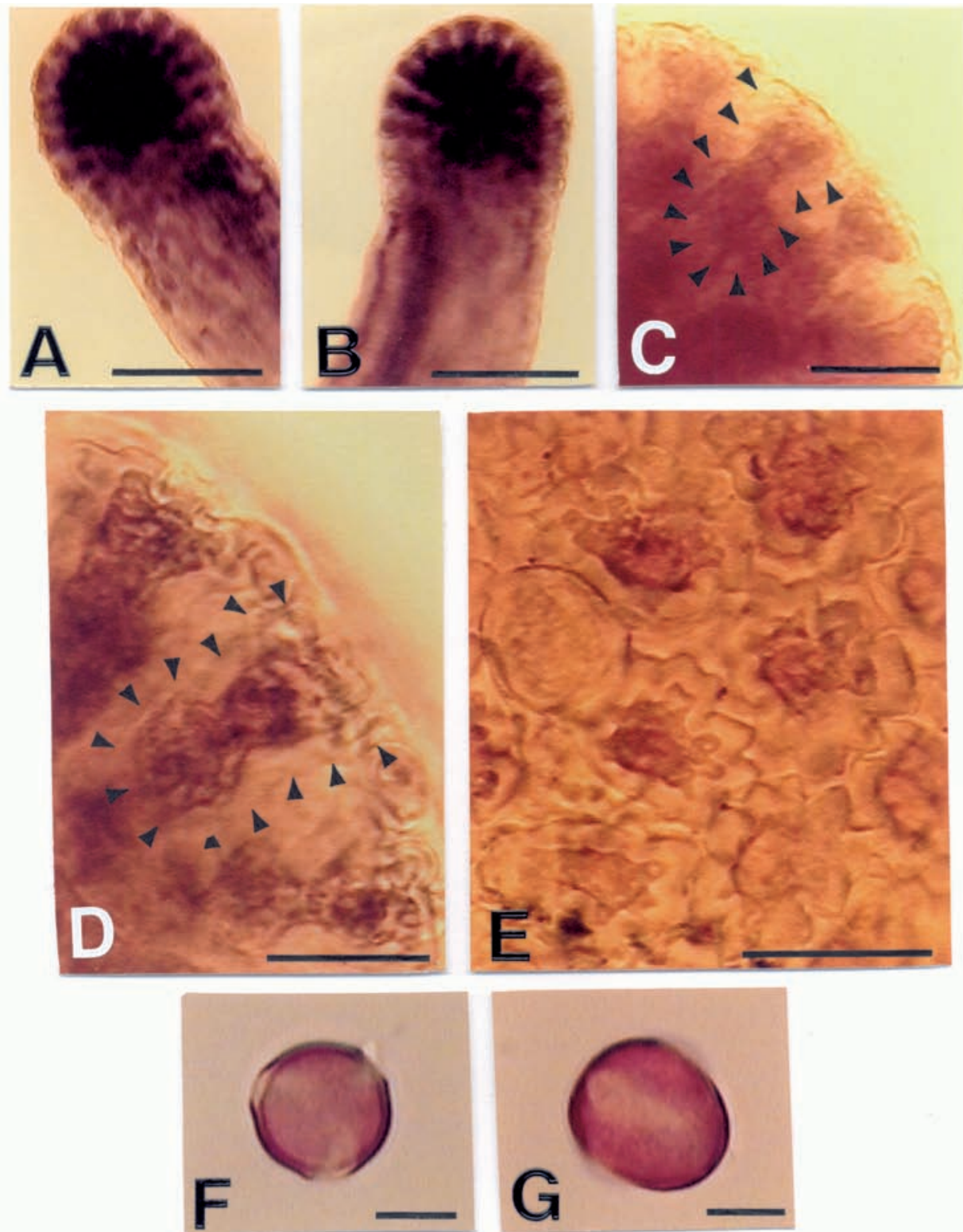

Fig. 4. Stigma of the pistil after treatment with Lugol's iodine solution and pollen grains of E. vulgare (LM).

A, B - Stigmas of the pistil with visible papillae. Bar $=100 \mu \mathrm{m}$.

C, D - Longitudinal section portions of the stigma with elongated papillae (arrowheads). C, D - Bar $=20 \mu \mathrm{m}$.

$\mathrm{E}-$ Surface of the stigma papillae with visible dark cell content and light cell walls. Bar $=20 \mu \mathrm{m}$.

$\mathrm{F}, \mathrm{G}-$ Tricolporate pollen grains in different positions. Bar $=10 \mu \mathrm{m}$. 

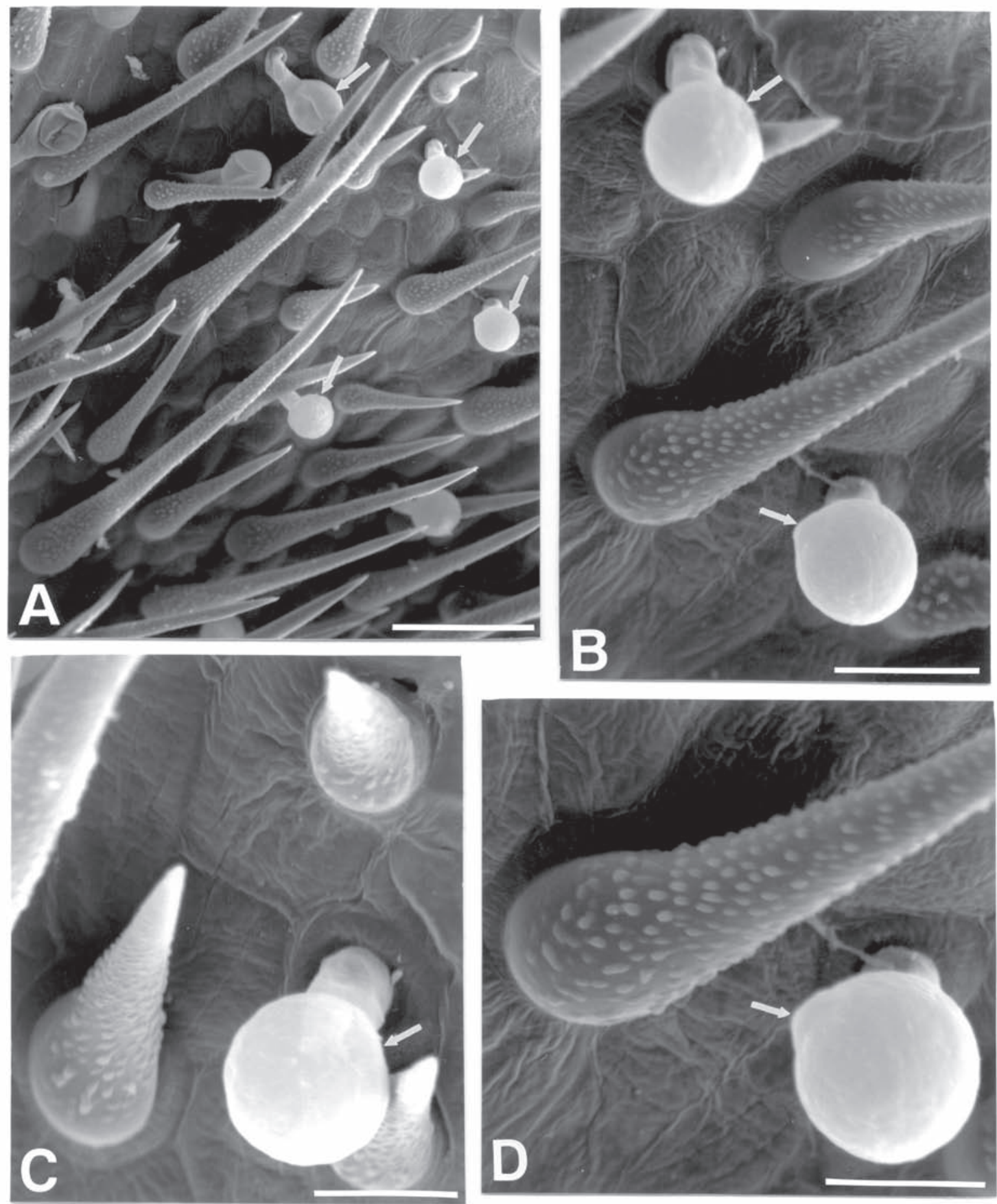

Fig. 5. Trichomes from the abaxial surface of the calyx of Echium vulgare.

A - Non-glandular trichomes of different length and glandular trichomes (arrows). Bar $=80 \mu \mathrm{m}$.

B, D - Glandular trichomes and portions of non-glandular trichomes. In glandular trichomes, visible protuberances of the cuticle with secretion (arrow), on the surface of non- glandular trichomes, visible wall protuberances. B $-\mathrm{Bar}=30$ $\mu \mathrm{m}, \mathrm{D}-\mathrm{Bar}=20 \mu \mathrm{m}$.

$\mathrm{C}$ - Short non-glandular trichomes and glandular trichomes. Bar $=20 \mu \mathrm{m}$. 


\section{DISCUSSION}

The nectary gland in the flowers of Echium vulgare, investigated in the present study, showed an average height of $330 \mu \mathrm{m}$, forming a collar-like projection with a radial width of $144 \mu \mathrm{m}$ at the basal part of the ovary of the pistil. The ovary diameter was about 960 $\mu \mathrm{m}$ and its height about $650 \mu \mathrm{m}$. The nectary of E. russicum, studied earlier by us (Chwil and Wery s zk o-Chmielewska, 2007), had much smaller dimensions $(234 \times 70 \mu \mathrm{m})$ compared to the data presented for $E$. vulgare, with a similar diameter and height of the ovary of the pistil for both species. In E. russicum, the ovary diameter was $900 \mu \mathrm{m}$. A comparison of corolla length in both species shows that in Echium vulgare the values of this parameter were within the range of $10-17 \mathrm{~mm}$, whereas for E. russicum it was $16-18 \mathrm{~mm}$. In both Echium species, the dimensions of the corolla length and the size of the ovary were similar, whereas in the flowers of E. russicum a much smaller nectary occurred. In both Echium species, nectar was secreted through anomocytic stomata. However, the distribution of the stomata on the surface of the gland differed significantly. In Echium russicum, they occurred only in the basal region of the nectary $(\mathrm{Chw}$ il and Weryszko-Chmi e lewska, 2007), whereas in E. vulgare they were distributed throughout its whole surface, with greater density in the lower part of the gland.

The average length and width of the nectarostomata of E. vulgare was 19 and $18 \mu \mathrm{m}$, respectively, which indicates their almost circular shape. We found similar dimensions (on the average $18.4 \mu \mathrm{m}$ ) of the circular-contoured nectarostomata in E. russicum in our earlier study (Chwil and Weryszko$\mathrm{Ch}$ mi e l ew ska, 2007). The distribution of the stomata over the whole surface of the nectary in E. vulgare is also associated with their larger number (462), compared to the number of nectarostomata found in E. russicum (184) only in the lower region of its much smaller nectary.

We compared the length of mature stomata found in the leaves of $E$. vulgare. Their average dimensions $(26 \times 23 \mu \mathrm{m})$ differed markedly from the size of the nectarostomata. The largest stomata in the leaves had the ratio of length to width equal to 1.2 , whereas the smaller ones, not fully mature, were round-contoured, similarly to the nectarostomata, with the ratio of length to width close to 1 . Hence, it can be stated that the nectarostomata resembled juvenile stomata of the leaves.

The papillae covering the capitate stigma of the pistil in E. vulgare were distinguished by a characteristic shape. They were made up of single cells with the lower part in the form of a small massive stalk and the upper part expanded and taking the shape of an umbrel- la with corrugated edges. In buds and young flowers, the folded edges of the anticlinal walls of the adjacent papillae tightly adhered to each other; in older flowers different-sized free spaces were visible between them.

In species of the family Boraginaceae, the occurrence of different-shaped papillae on the stigmas was demonstrated. Similar papillae to those observed by us in E. vulgare, in terms of their shape, are found in $E$. plantagineum (Relief and van Vyk, 1998) and in Pulmonaria obscura (O les e n, 1979). But in other species, the papillae of the stigma differ substantially in the structure of the upper part. The papillae in Anchusella cretica and A. variegata as well as in Lycopsis arvensis (B i g a z z i et al. 1997) and Symphytum officinale (M a s i e rowska and Spiczyńska, 2005) show various shapes. The authors of the latter paper have shown that only the basal portions are the receptive part of the papillae of the stigma in Symphytum officinale. He s lo p - H a r r i s o n (1981) has found that pollen grains with their size appropriate for this species are pushed between the papillae of the stigma by insects and they germinate to form pollen tubes only there. However, pollen grains remaining on the surface of the stigma are not able to germinate. The upper part of the papillae, forming an "umbrella" in Echium, may protect pollen grains against insolation ( $\mathrm{He} \mathrm{s} \mathrm{lop-Harri-}$ s o n, 2000).

In the present study we have shown that nonglandular and glandular trichomes occur on the sepals of E. vulgare. But A neli (1975) has distinguished only bristly hairs in Boraginaceae representatives of the genus Onosma, whereas Selvi and Bigazzi (2001) as well as Taia (2006) have also found the occurrence of glandular trichomes in different representatives of this family, in addition to non-glandular trichomes.

\section{REFERENCES}

Aneli N. A. 1975. Atlas of leaf epidermis. Mecniereba, Tbilisi (in Russian).

Beales K. A., Betteridge K., Colegate S. M, Edgar J. A. 2004. Solid-phase extraction and LC-MS analysis of pyrrolizidine alkaloids in honeys. J. Agric. Food Chem. 52 (21): 6664-6672.

Bigazzi M., Nordi E., Selvi F. 1997. Anchusella, a new genus of Boraginaceae from the Central-Eastern Mediterranean. Plant Syst. Evol. 205: 241-264.

Boppre M., Colegate S. M., Edgar J. A. 2005. Pyrrolizidine alkaloids of Echium vulgare honey found in pure pollen. J. Agric. Food Chem. 53 (3): 594-600.

Chwil. M., Weryszko-Chmielewska E. 2007. Nectary structure and nectar secretion of Echium russicum J. F. Gmel. flowers. Acta Agrobot. 60 (1): 25-33. 
Heslop-Harris on Y. 1981. Stigmatic characteristics and angiosperm taxonomy. Nor. Bot. 1: 401-420.

Heslop-Harrison Y. 2000. Control gates and micro-ecology: the pollen-stigma interaction in perspective. Ann. Bot. 85: 5-13.

Jabłoński B. 1986. Nektarowanie i wydajność miodowa ważniejszych roślin miododajnych $\mathrm{w}$ warunkach Polski. / Nectar secretion and honey productivity of important honey plants in Polish condition. Cz. V. Pszczel. Zesz. Nauk. 30: 195-205.

Kołtowski Z. 2006. Wielki atlas roślin miododajnych. / The Great Atlas of Melliferous Plants. Przedsiębiorstwo Wydawnicze Rzeczpospolita SA, Warszawa.

Masierowska M., Stypiczyńska M. 2005. Stigma receptivity in comfrey (Symphytum officinale L.) during the course of anthesis. Isr. J. Plant Sci. 53: 41-46.

Olesen J. M. 1979. Floral morphology and pollen flow in the heterostylous species Pulmonaria abscura Dumont (Boraginaceae). New Phytol. 82: 757-767.

Retief E., Van Wyk A. E. 1998. The genus Echium (Boraginaceae) in southern Africa. Bothalia, 28 (2): 167-177.

Rutkowski L. 2006. Klucz do oznaczania roślin naczyniowych Polski niżowej. Wydawnictwo Naukowe PWN, Warszawa.

Selvi F., Bigazzi M. 2001. Leaf surface and anatomy in Boraginaceae tribe Boragineae with respect to ecology and taxonomy. Flora, 196 (4): 269-285.

Šomsač L. (Red.) 1984. Świat roślin, skał i minerałów. / The world of plants, rocks and minerals. Państwowe Wydawnictwo Rolnicze i Leśne, Warszawa.

Szafer W. 1986. Rośliny polskie. Państwowe Wydawnictwo Naukowe, Warszawa.

Taia W. K. 2006. Family Boraginaceae: Hair variations and their significans in the systematic of the genera. Asian. Plant Sci. 5 (3): 441-454.

\section{Mikromorfologia struktur wydzielniczych w kwiatach Echium vulgare L.}

\author{
Streszczenie
}

Badano mikromorfologię wybranych elementów kwiatów Echium vulgare L. ze szczególnym uwzględnieniem struktury nektarników i znamienia słupka oraz typów włosków występujących na powierzchni kielicha.

Nektarnik miał kształt nierównego dysku położonego wokół dolnej części czterodzielnej zalążni słupka. Komórki gruczołowe tworzyły pokład o wysokości $330 \mu \mathrm{m}$ i szerokości promieniowej równej $144 \mu \mathrm{m}$. Nektar wydostawał się na powierzchnię nektarnika przez anomocytyczne aparaty szparkowe, położone na poziomie innych komórek epidermy. Aparaty szparkowe $\mathrm{w}$ większości były otwarte ze zróżnicowaną rozwartością poru. Największą ich liczbę obserwowano przy podstawie nektarnika, zaś na całej powierzchni nektarnika odnotowano 460 szparek. Kutykula na powierzchni komórek szparkowych tworzyła delikatne, koliste prążki. Komórki przyszparkowe wykształcały prążkowaną ornamentację kutykularną z prążkami ułożonymi promieniście w kierunku szparki, zaś na powierzchni innych komórek epidermy prążki tworzyły różnokierunkowy układ.

Epiderma na powierzchni znamienia wykształcała regularnie ułożone papille $\mathrm{z}$ wachlarzowato rozszerzoną górną częścią o karbowanych ścianach zewnętrznych, zaś nasada komórki tworzyła maczugowatą kolumienkę.

Epiderma odosiowej części kielicha była pokryta licznymi włoskami mechanicznymi o zróżnicowanej długości, które zbudowane były z jednej lub kilku komórek. Włoski gruczołowe w epidermie kielicha wyrastały $\mathrm{w}$ mniejszym zagęszczeniu w porównaniu z trichomami ochronnymi i były utworzone z 1-2 komórkowego trzonka i wydzielniczej główki. 